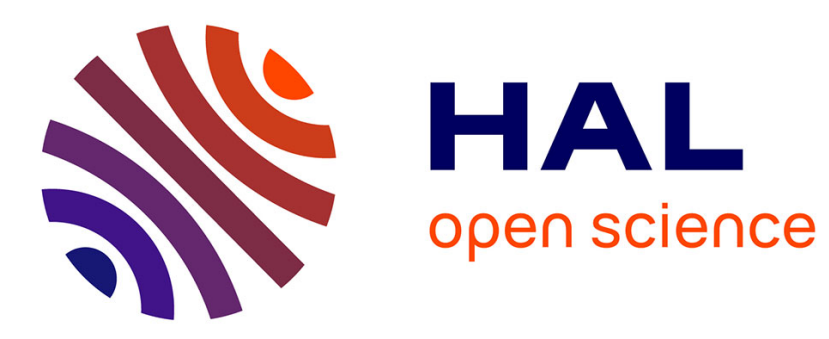

\title{
Lymphocytotoxic autoantibodies
}

Yves Renaudineau, Jacques-Olivier Pers, Pierre Youinou

\section{To cite this version:}

Yves Renaudineau, Jacques-Olivier Pers, Pierre Youinou. Lymphocytotoxic autoantibodies. Autoantibodies, Elsevier, pp.535-541, 2013, 10.1016/B978-0-444-56378-1.00063-0 . hal-00936954

\section{HAL Id: hal-00936954 \\ https://hal.univ-brest.fr/hal-00936954}

Submitted on 4 Dec 2017

HAL is a multi-disciplinary open access archive for the deposit and dissemination of scientific research documents, whether they are published or not. The documents may come from teaching and research institutions in France or abroad, or from public or private research centers.
L'archive ouverte pluridisciplinaire HAL, est destinée au dépôt et à la diffusion de documents scientifiques de niveau recherche, publiés ou non, émanant des établissements d'enseignement et de recherche français ou étrangers, des laboratoires publics ou privés. 


\title{
Lymphocytotoxic Autoantibodies
}

\author{
Yves Renaudineau, Jacques-Olivier Pers, and Pierre Youinou \\ Brest University Medical School, EA2216 Immunology, Pathology and Immunotherapy, Brest, France
}

\section{Historical notes}

Patients previously immunized with multiple transfusions, pregnancy, or organ transplantation were initially shown to develop antibodies (Ab) with cytotoxic activity against allogenic lymphocytes. Later, allogenic-independent lymphocytotoxins were described in patients with infectious diseases. These infection-related lymphocytotoxins possess two characteristics: first, they are immunoglobulin (Ig) $\mathrm{M}$-like in nature, and second, they present optimal activity at $15{ }^{\circ} \mathrm{C}$. Accordingly, they are referred to as cold lymphocytotoxins (CLTs). Finally, using a mixed lymphocyte cytotoxic (MLC) assay, developed for histocompatibility testing, the presence of autologous lymphocytotoxic Ab (LCA) was tested and demonstrated, even at $37{ }^{\circ} \mathrm{C}$, in patients with systemic lupus erythematosus (SLE). These LCA appeared to reflect the clinical course of SLE and to target T rather than B lymphocytes. Furthermore, they were relatively specific for mitogen-activated $\mathrm{T}$ lymphocytes and shown to recognize predominantly different isoforms of CD45. All of these $\mathrm{Ab}$ are referred to as LCA.

\section{The autoantigens}

\section{Definition}

Sera reactive for LCA react with: 1) peripheral blood mononuclear cells (PBMC) obtained from healthy donors; 2) T and B lymphocytes isolated from PBMC; 3) cells from permanent T- and B-cell lines; and 4) cytokine or pokeweed mitogen activated lymphocytes.

LCA are not lymphocyte-specific since the activity can be partially inhibited by absorption with brain tissue, red blood cells, and platelets. The binding is not mediated by Fc receptors.

\section{CD45 is the main target}

The leukocyte common antigen CD45 is an essential tyrosine phosphatase for efficient T- and B-lymphocyte antigen receptor signal transduction. Five CD45 isoforms can be generated by alternative splicing of exons 4(A), 5(B), and 6(C) that encode the corresponding domains at the N-terminal extracellular portion of the protein (Fig. 63.1). These glycoproteins vary both in size, with a molecular weight ranging from 180 to $240 \mathrm{kDa}$, and in glycosylation, with $\mathrm{N}$ - and/or O-linked polysaccharides. Isoforms and carbohydrate composition are related to the T- or B-lymphocyte subsets and to the lymphocyte maturation and differentiation status [1]. 


\section{Neuraminidase \\ No Yes}

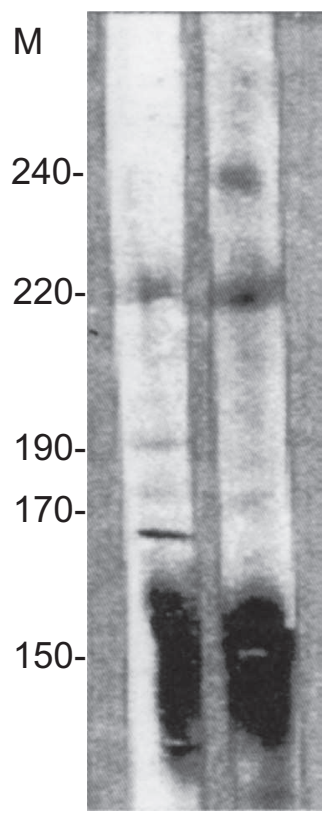

FIGURE 63.1

CD45 autoantibodies in a lupus patient. Removal of sialic acid by neuraminidase reveals a new CD45 isoform.

According to the origin of the LCA, CD45 isoform recognition may be different. Indeed, IgM cold reactive LCA appear to preferentially recognize a nonsialylated O-glycosyl carbohydrate determinant present in resting and activated $\mathrm{T}$ cells in contrast to warm IgG reactive LCA that preferentially bind sialylated determinants [2]. Among warm IgG LCA, some of them recognize specific CD45RO carbohydrates expressed preferentially by activated peripheral T cells [3]. Of particular note, the pathogenic anti-i cold agglutinin crossreacts with the naïve B-cell-specific CD45 isoform and the N-acetyl galactosamin determinant present on the erythrocyte antigen [4].

\section{Human leukocyte antigen and $\beta 2$ microglobulin}

In SLE and other autoimmune diseases tested, a relation between LCA and anti-human leukocyte antigen (HLA) specificity was not observed. Nevertheless, in up to $50 \%$ of patients with SLE, the introduction of $\beta 2$ microglobulin in the MCL assay reduces LCA activity, thus suggesting that anti- $\beta 2$ microglobulin Abs are part of the LCA spectrum. In contrast, the crossreactivity with $\beta 2$-microglobulin was not reproduced when using LCA from patients with infectious diseases. IgG anti- $\beta 2$ microglobulin Abs are detected, and their prevalence ranges from 30-70\% [5]. These anti- $\beta 2$ microglobulin Abs are associated with disease progression, prevention of mitogen-induced lymphocyte proliferation, and platelet functions. Anti- $\beta 2$ microglobulin Abs detection in SLE is independent from $\beta 2$-microglobulin levels that are increased in active patients. 


\section{Other targets}

Detected in SLE patients, anti-ribosomal P0 Abs are associated with neuropsychiatric, hepatic and renal diseases and lymphopenia. When present in SLE patients, anti-ribosomal P0 Abs recognize the P0 38-kDa phosphoprotein present at the cell surface of resting and activated T cells [6]. The specificity is not restricted to lymphocytes since LCA Ab also bind brain cell lines (Table 63.1).

LCA-positive sera contain other Ab that recognize other T-lymphocyte receptors. Among them, Anti-TCR/CD3 Ab present in SLE sera can bind to $\mathrm{T}$ cells and contribute to interleukin (IL)-2 downregulation. As well, LCA anti-T-cell costimulatory molecules such as anti-CTLA-4 (CD152), anti-B7-H1 (CD274), and anti-IL-2 receptor (CD25) are generated in autoimmune diseases and may modulate the immune response. Anti-beta-2 glycoprotein I, anti-CD40, and anti-B- and T-cell receptor antigen have been described also.

\section{The autoantibodies}

\section{Definition}

Three subgroups of LCA can be distinguished (Table 63.2).

1. Warm reactive $\left(37^{\circ} \mathrm{C}\right), \mathrm{IgG}$, complement dependent or not, and directed against HLA antigens. They are associated with an immunization through blood transfusions, pregnancies, or transplantation. Utilization of anti-HLA class I or class II antiserum confirm the MHC specificity of the LCA.

\begin{tabular}{|c|c|c|c|c|}
\hline Target & $\lg$ & Cells & Effect & Disease \\
\hline CD45 (desialyl o-link) & $\lg M$ & T cells & ADCC & Infection \\
\hline $\begin{array}{l}\text { CD45 (N-acetyl } \\
\text { galactosamine) }\end{array}$ & $\operatorname{lgM}, G\left(V_{H} 4034\right)$ & naïve B cells & Apoptosis & SLE \\
\hline $\begin{array}{l}\beta 2 \text { microglobulin, HLA } \\
\text { class I/II }\end{array}$ & $\operatorname{lgM}, \lg G$ & B cells & Unknown & $\begin{array}{l}\text { Alloimmunization, } \\
\text { SLE }\end{array}$ \\
\hline Ribosomal Po & $\lg G$ & $\mathrm{~T}, \mathrm{~B}$ cells & Cytotoxicity & SLE \\
\hline$\beta 2$ glycoprotein I & $\lg G$ & Lymphocytes & Unknown & SAPL, SLE \\
\hline $\mathrm{TCR} / \mathrm{CD} 3$ & $\lg G$ & $\mathrm{~T}$ cells & $\begin{array}{l}\text { Repress IL-2 } \\
\text { synthesis }\end{array}$ & SLE \\
\hline $\lg \mathrm{D}$ & $\lg M, G$, and $A$ & B cells & Unknown & SLE, RA, MCTD \\
\hline IL-2 receptor (CD25) & $\lg G$ & Activated T cells & Unknown & SLE \\
\hline CTLA-4 (CD152) & $\operatorname{lgG}$ & Activated T cells & Proliferation & RA, Behçet \\
\hline B7-H1 (CD274) & $\lg G$ & Activated T cells & Apoptosis & RA \\
\hline CD40 & $\lg G$ & B cells & Unknown & SAPL, SLE \\
\hline $\begin{array}{l}\text { DNA or a cross- } \\
\text { reactive molecule }\end{array}$ & $\lg M$ & $\mathrm{~T}, \mathrm{~B}$ cells & Cytotoxicity & SLE \\
\hline
\end{tabular}


Table 63.2 Comparison of IgM and IgG Antilymphocyte Autoantibodies

\begin{tabular}{|c|c|c|c|}
\hline & $\lg M$ & $\lg G>\lg M$ & $\lg G>\lg M$ \\
\hline & Cold Reactive $\left(15^{\circ} \mathrm{C}\right)$ & Warm Reactive $\left(37^{\circ} \mathrm{C}\right)$ & Warm Reactive $\left(37^{\circ} \mathrm{C}\right)$ \\
\hline Disease association & Infection, autoimmunity & Alloimmunization & Autoimmunity \\
\hline Cell specificity & T cells $>$ B cells & T and B cells & $\mathrm{T}$ and $\mathrm{B}$ cells \\
\hline Complement & Yes & No (yes) & No \\
\hline Main target & CD45 & HLA class $1 / \| 1$ & $\begin{array}{l}\text { CD } 45, \beta \text { microglobuin, } \\
\text { and other targets }\end{array}$ \\
\hline Cytotoxicity & Complement dependent & Direct apoptosis & Variable \\
\hline
\end{tabular}

2. Warm reactive $\left(37^{\circ} \mathrm{C}\right), \operatorname{IgG}$, usually noncomplement dependent, directed against non-HLA molecules, and present in autoimmune diseases.

3. Cold reactive $\left(15^{\circ} \mathrm{C}\right)$, IgM, and complement dependent. These natural Abs referred to as CTLs predominate in infectious diseases and can be found in autoimmune diseases.

\section{Lymphocytotoxicity}

The MLC assay used for histocompatibility assaying has been adapted to distinguish cold $\left(15^{\circ} \mathrm{C}\right)$ from warm $\left(37^{\circ} \mathrm{C}\right) \mathrm{Abs}$ and noncomplement-dependent from complement-dependent Abs [7].

\section{Lymphocyte activation}

In the presence of LCA purified from SLE patients, lymphocytes from healthy donors can acquire some characteristics of lymphocytes from SLE. This includes TLR-antigen presentation and cytokine production [8]. In addition, T-cell proliferation mediated by phytohemagglutinin is inhibited, as well as the effect of pokeweed mitogen on B-cell immunoglobulin synthesis.

\section{Genetics}

Consanguineous relatives of SLE and rheumatoid arthritis (RA) patients may possess LCA, suggesting that these Ab are genetically controlled. Using an MLC assay, Eroglu and Kohler have tested LCA positivity within SLE patients and their relatives [9]. LCA positivity was $83 \%$ in the SLE group and 50\% in the consanguineous relative group, versus $11 \%$ in the nonconsanguineous group and $5 \%$ in the healthy control group.

\section{Methods of detection}

The standard method for the detection of LCA is an adapted MLC assay, in which the presence of LCAmediated complement cytolysis is tested using peripheral blood lymphocytes from healthy donors. Several parameters need attention. First, the reaction has to be conducted at $15^{\circ} \mathrm{C}$ to ensure the binding of all LCA subgroups. Second, the source of complement is critical. In this situation, a human serum is 
preferred instead of rabbit serum, which contains heterologous LCA. Autologous LCA may be present in human sera and must be eliminated first. Third, fresh cells instead of frozen cells have to be used to avoid cell susceptibility to lysis and false-positive results. The usual cutoff to define a positive test is $10 \%$ but may vary according to the laboratory.

The MLC test presents several disadvantages. Viable cells are required. Activation of complement is necessary, leading to the inability to detect noncomplement-dependent Abs. All determinants may not be present on lymphocytes, such as antigens that are only transiently expressed or induced by activation. Differentiation between IgA versus IgG LCA and between CD45 and non-CD45 LCA is also not possible with the standard MLC assay. Therefore, several techniques were introduced as alternatives to the MLC test in order to overcome the MLC problems. These are based on immunofluorescence, enzyme-linked immunosorbent assay (ELISA), flow cytometry (FACS), and immunoblotting.

The ELISA test permits presentation of purified antigens, instead of living lymphocytes, as targets for the binding of Ab. Furthermore, this method permits differentiation of $\operatorname{IgM}, \operatorname{IgG}$, and $\operatorname{IgA~} \mathrm{Ab}$. Characterized antigen-coated microparticles can be used as targets for determination of $\mathrm{Ab}$ specificity.

The FACS Ab screen detects Ab binding independently from the complement activation and also detects small amounts of Ab. Thus, it is more sensitive. Discrimination between $\operatorname{IgM}, \operatorname{IgG}$, and $\operatorname{IgA~Ab}$ may be done also.

Using immunoblotting, crude lymphocyte preparations can confirm the presence of the Abs to antigens of defined size.

\section{Clinical utility \\ Disease association}

LCA were first described in patients with infectious agents: bacteria (Mycobacterium tuberculosis, M. leprae), virus (human immunodeficiency virus, Influenzae virus, herpes virus, Epstein-Barr virus), fungi, and parasites. In tuberculosis, LCA have been associated with the extent of lung involvement and the disease severity, but these associations were restricted to B-cell-specific LCA.

LCA are frequently encountered in active autoimmune diseases such as SLE, Sjögren syndrome, RA, primary biliary cirrhosis, myasthenia gravis, and multiple sclerosis (Table 63.3). LCA have been reported also in nonautoimmune diseases such as cancers.

Table 63.3 Lymphocytotoxic Autoantibodies and Diseases

Disease

Systemic lupus erythematosus

Sjögren syndrome

Rheumatoid arthritis

Myasthenia gravis

Primary biliary cirrhosis

Cancer

Multiple sclerosis

\section{Prevalence}

60-90\%

$50 \%$

$32 \%$

$36 \%$

$57 \%$

Variable

20-80\% 


\section{Lymphopenia}

Antibody-dependent cell cytotoxicity (ADCC) of peripheral blood lymphocytes is a possible mechanism by which LCA may mediate in vivo lymphocytolysis. But, to date, a direct relationship between LCA and lymphopenia has not been clearly established. Modulation of cytokine production by LCA is another mechanism by which LCA may contribute to lymphopenia.

\section{Nephritis}

LCA appears to correlate with the presence of active lupus nephritis, concomitant with a reduction of the circulating CD4+ CD45RA(2H4)+ population, a reduction of serum complement, and a high level of circulating anti-deoxyribonucleic acid (DNA) Ab. Although associated with anti-dsDNA Ab, LCA and anti-DNA Ab titer are not correlated, suggesting different mechanisms for the production of these Abs.

\section{Central nervous system}

The presence of LCA has been associated with neurologic manifestations in SLE patients. Purified LCA could be absorbed on brain tissue, thereby supporting a possible role of LCA in the development of neurologic manifestations in SLE patients. The relation between LCA and central nervous system manifestations in SLE was not confirmed in all studies.

Five specific T-cell antigenic targets were associated with neuropsychiatric lupus: the ribosomal P0 38-kDa phosphoprotein and uncharacterized bands at 19, 50, 55, and $98 \mathrm{kDa}$.

\section{Spontaneous Abortion}

LCA have been involved in reproductive failure in some patients with SLE. Nevertheless, the description of the antiphospholipid Abs, such as anticardiolipin anti-beta2-glycoprotein I, have reduced the importance of LCA in abortion.

\section{Take-home messages}

- Patients with SLE develop anti-LCA measured by the complement-dependent MLC assay.

- LCA may induce direct apoptosis, complement-dependent cytotoxicity, ADCC, and cell activation with cytokine production, suggesting that LCA have the potential to influence lymphocyte functions.

- An increased incidence of LCA in consanguinity with lupus patients is described, suggesting that these Abs are genetically controlled.

\section{References}

[1] Winfield JB. Are anti-ribosomal P protein antibodies a type of anti-lymphocyte antibody? Clin Exp Immunol 1997;109:1-3.

[2] Mimura T, Fernsten P, Jarjour W, Winfield JB. Autoantibodies specific for different isoforms of CD45 in systemic lupus erythematosus. J Exp Med 1990;172:653-6. 
[3] Mamoune A, Saraux A, Delaunay JL, Le Goff P, Youinou P, Le Corre R. Autoantibodies to CD45 in systemic lupus erythematosus. J Autoimmunity 1998;11:485-8.

[4] Cappione AJ, Pugh-Bernard AE, Anolik JH, Sanz I. Lupus IgG VH4.34 antibodies bind to a 220-kDa glycoform of CD45/B220 on the surface of human B lymphocytes. J Immunol 2004;172:4298-307.

[5] Olsen NJ, Li QZ, Quan J, Wang L, Mutwally A, Karp DR. Autoantibody profiling to follow evolution of lupus syndromes. Arthritis Res Ther 2012;14; R174.

[6] Stafford HA, Chen AE, Anderson CJ, Paul AG, Wyatt EL, Lee LA, et al. Anti-ribosomal and 'P-peptide'-specific autoantibodies bind to T lymphocytes. Clin Exp Immunol 1997;109:12-9.

[7] Mamoune A, Kerdreux S, Durand V, Saraux A, Goff PL, Youinou P, et al. CD45 autoantibodies mediate neutralization of activated T cells from lupus patients through anergy or apoptosis. Lupus 2000;9:622-31.

[8] Kammer GM. Altered regulation of IL-2 production in systemic lupus erythematosus: an evolving paradigm. J Clin Invest 2005;115:836-40.

[9] Eroglu GE, Kohler PF. Familial systemic lupus erythematosus: the role of genetic and environmental factors. Ann Rheum Dis 2002;61:29-31. 